\title{
PRODUCTION AND PROPERTIES OF AN EXTRACELLULAR PROTEASE FROM THERMOPHILIC BACILLUS SP
}

\author{
Wellingta Cristina Almeida do Nascimento; Meire Lelis Leal Martins* \\ Centro de Ciências e Tecnologias Agropecuárias, Universidade Estadual do Norte Fluminense Darcy Ribeiro, \\ Campos dos Goytacazes, RJ, Brasil.
}

Submitted: February 03, 2003; Returned to authors: June 03, 2003; Approved: March 04, 2003.

\begin{abstract}
Protease production by thermophilic Bacillus sp strain SMIA-2 cultivated in liquid cultures containing trisodium citrate reached a maximum in $9 \mathrm{~h}$, with levels of $1.93 \mathrm{U} / \mathrm{mg}$ protein. The microorganism utilized several carbon sources for the production of protease. Starch was the best substrate, followed by trisodium citrate, citric acid and sucrose. Among the various organic and inorganic nitrogen sources, ammonium nitrate was found to be the best. Studies on the protease characterization revealed that the optimum temperature of this enzyme was $60^{\circ} \mathrm{C}$. The enzyme was stable for $2 \mathrm{~h}$ at $30^{\circ} \mathrm{C}$, while at $40^{\circ} \mathrm{C}$ and $80^{\circ} \mathrm{C}, 14 \%$ and $84 \%$ of the original activities were lost, respectively. The optimum $\mathrm{pH}$ of the enzyme was found to be 8.0. After incubation of crude enzyme solution for $24 \mathrm{~h}$ at $\mathrm{pH} 5.5,8.0$ and 9.0 , a decrease of about $51 \%, 18 \%$ and $66 \%$ of its original activity was observed respectively. A stronger inhibitory effect was observed in the presence of $\mathrm{K}^{+}, \mathrm{Hg}^{2+}$ and $\mathrm{Cu}^{2+} . \mathrm{Hg}^{+}$resulted in the complete loss of activity at $1 \mathrm{mM}$ concentrations. Activity was stimulated by $\mathrm{Mn}^{2+}$ and $\mathrm{Ca}^{+2}$, indicating that these ions had a functional role in the molecular structure of the enzyme.
\end{abstract}

Key words: protease, thermophilic bacterium, Bacillus sp

\section{INTRODUCTION}

Proteases [serine protease (EC. 3.4.21), cysteine (thiol) protease (EC 3.4.22), aspartic proteases (EC 3.4.23) and metalloprotease (EC 3.4.24)] constitute one of the most important groups of industrial enzymes, accounting for about $60 \%$ of the total enzyme market $(12,19,23)$. Among the various proteases, bacterial proteases are the most significant, compared with animal and fungal proteases (24) and among bacteria, Bacillus sp are specific producers of extra-cellular proteases (17). These enzymes have wide industrial application, including pharmaceutical industry, leather industry, manufacture of protein hydrolizates, food industry and waste processing industry (13).

Thermostable proteases are advantageous in some applications because higher processing temperatures can be employed, resulting in faster reaction rates, increase in the solubility of nongaseous reactants and products, and reduced incidence of microbial contamination by mesophilic organisms. Proteases secreted from thermophilic bacteria are thus of particular interest and have become increasingly useful in a range of commercial applications $(1,18,19,21,23)$.

Recently, a thermophilic Bacillus sp strain SMIA-2 was isolated from a soil sample collected in Campos dos Goytacazes city, Rio de Janeiro, Brazil $(11,12)$. Phylogenetic analysis showed that this strain is a member of the Bacillus rRNA group 5. This group includes Bacillus stearothermophilus and other thermophilic Bacillus spp.

In this article, we describe the selection of medium components for the optimal production of extracellular protease by thermophilic Bacillus sp strain SMIA-2, along with some biochemical properties of the enzyme.

*Corresponding author. Mailing address: Centro de Ciências e Tecnologias Agropecuárias, Universidade Estadual do Norte Fluminense Darcy Ribeiro. Av. Alberto Lamego, 2000. 28013-600. Campos dos Goytacazes, RJ. Brasil. Tel.: (+5522) 27261460. Fax: (+5522) 27263875. E-mail: meire@uenf.br 


\section{MATERIALS AND METHODS}

\section{Organism}

The bacterial strain used in this study was the thermophilic Bacillus sp strain SMIA-2, previously isolated from a soil sample collected in Campos dos Goytacazes City, Rio de Janeiro, Brazil $(11,12)$.

\section{Enzyme production}

The culture medium used in this work for protease production contained $\left(\mathrm{g} / \mathrm{L}\right.$ of destilled water): $\mathrm{MgSO}_{4}-0.5$, $\mathrm{K}_{2} \mathrm{HPO}_{4}-2.0, \mathrm{KCl}-0.3, \mathrm{NH}_{4} \mathrm{NO}_{3}-10.0$, peptone-1.0. Trisodium citrate-10.0. The $\mathrm{pH}$ was adjusted to 6.9-7.0 with $1.0 \mathrm{M} \mathrm{NaOH}$ and this basal medium was sterilized by autoclaving at $121^{\circ} \mathrm{C}$ for $15 \mathrm{~min}$. Peptone was sterilized separately and aseptically added to the flasks containing the liquid medium, after cooling. The above medium ( $50 \mathrm{~mL}$ in $250 \mathrm{~mL}$ Erlenmeyer flasks) was inoculated with $1 \mathrm{~mL}$ of an overnight culture and incubated at $50^{\circ} \mathrm{C}$ in a rotary shaker operated at $150 \mathrm{rpm}$ for $12 \mathrm{~h}$. At time intervals, the turbidity of the cultures was determined by measuring the increase in optical density at $470 \mathrm{~nm}$ with a spectrophotometer Hitachi Model U-2000. Before assay, the cells were separed by centrifugation at $15.500 \mathrm{~g}$ for $15 \mathrm{~min}$ and the clear supernatant was used as crude enzyme preparation.

\section{Effect of culture conditions on enzyme production}

The culture medium was supplemented with the following metal traces $(\mathrm{g} / \mathrm{L}): \mathrm{CaCl}_{2}-2.2 \times 10^{-3}, \mathrm{ZnO}-2.5 \times 10^{-3}, \mathrm{FeCl}_{3} \cdot 6 \mathrm{H}_{2} \mathrm{O}-$ $2.7 \times 10^{-2}, \mathrm{MnCl}_{2} .4 \mathrm{H}_{2} \mathrm{O}-1.0 \times 10^{-2}, \mathrm{CuCl}_{2} .2 \mathrm{H}_{2} \mathrm{O}-8.5 \times 10^{-4}, \mathrm{CoCl}_{2} .6 \mathrm{H}_{2} \mathrm{O}-$ $2.4 \times 10^{-3}, \mathrm{NiCl}_{3} .6 \mathrm{H}_{2} \mathrm{O}-2.5 \times 10^{-4}, \mathrm{H}_{3} \mathrm{BO}_{3}-3.0 \times 10^{-4}$ and $\mathrm{Na}_{2} \mathrm{MoO}_{4}-$ $1.0 \times 10^{-3}$. The effects of carbon sources $1 \%(\mathrm{w} / \mathrm{v})$ on enzyme secretion were investigated replacing trisodium citrate by glycerol, $\mathrm{D}(+)$ galactose, lactose, sucrose, maltose, starch, $\mathrm{D}(+)$ glucose, $\mathrm{D}(+)$ manose, $\mathrm{L}(+)$ arabinose, casein, $\mathrm{D}(+)$ xylose and citric acid. Different nitrogen sources including $\mathrm{NH}_{4} \mathrm{NO}_{3}$, peptone, yeast extract, meat extract, casein, $(\mathrm{NH} 4)_{2} \mathrm{SO}_{4}$, $\left(\mathrm{NH}_{4}\right)_{2} \mathrm{HPO}_{4}, \mathrm{NH}_{4} \mathrm{Cl}, \mathrm{KNO}_{3}$, urea and ammonium citrate were employed in preliminary studies to determine growth and production of extracellular protease.

\section{Enzyme assay}

The activity of protease was assessed in triplicate by measuring the release of trichloroacetic-acid soluble peptides from $0.2 \%(\mathrm{w} / \mathrm{v})$ azocasein in $50 \mathrm{mM}$ HEPES/NaOH buffer $(\mathrm{pH}$ 7.5 ) at $50^{\circ} \mathrm{C}$ for $10 \mathrm{~min}$. The $1-\mathrm{mL}$ reaction was terminated by the addition of $0.5 \mathrm{~mL}$ of $15 \%$ trichloroacetic acid and then centrifuged at $10.000 \mathrm{~g}$ for $10 \mathrm{~min}$, after cooling. One unit (U) enzyme activity was defined as the amount of enzyme required to produce an increase in absorbance at $420 \mathrm{~nm}$ equal to $1.0 \mathrm{in}$ $60 \min (7)$.

Protein was measured by the method of Lowry, as modified by Petterson (14).

\section{Effect of $\mathrm{pH}$ on activity and stability of protease}

The optimum $\mathrm{pH}$ was determined with azocasein $1 \%(\mathrm{w} / \mathrm{v})$ as substrate dissolved in different buffers (citrate phosphate, $\mathrm{pH}$ 5-6, sodium phosphate, $\mathrm{pH} 7.0$, Tris- $\mathrm{HCl}, \mathrm{pH} 8.0$ and glycine $\mathrm{NaOH}, \mathrm{pH} 9-13)$. The effect of $\mathrm{pH}$ on enzyme stability was determined by pre-incubating the enzyme without substrate at different $\mathrm{pH}$ values (5.5-9.0) for $24 \mathrm{~h}$ at room temperature and measuring the residual activity at $60^{\circ} \mathrm{C}$.

\section{Effect of temperature on activity and stability}

The effect of temperature on the enzyme activity was determined by performing the standard assay procedure at $\mathrm{pH}$ 7.5 within a temperature range from 40 to $100^{\circ} \mathrm{C}$. Thermostability was determined by incubation of crude enzyme at temperatures ranging from $30-100^{\circ} \mathrm{C}$ for $2 \mathrm{~h}$ in a constant-temperature water bath. After treatment the residual enzyme activities were assayed.

\section{Effect of metal ions on protease activity}

The effect of different metal ions on protease activity was determined by the addition of the corresponding ion at a final concentration of $1.0 \mathrm{mM}$ to the reaction mixture, and assayed under standard conditions. The enzyme assay was carried out in the presence of $\mathrm{KCl}, \mathrm{CaCl}_{2}, \mathrm{MgSO}_{4}, \mathrm{FeSO}_{4}, \mathrm{CoCl}_{2}, \mathrm{ZnCl}_{2}$, $\mathrm{MnSO}_{4}, \mathrm{HgCl}_{2}, \mathrm{CuSO}_{4}$ and $\mathrm{NaCl}$.

\section{RESULTS AND DISCUSSION}

\section{Effect of culture conditions on enzyme secretion}

The growth pattern of Bacillus sp. SMI-2 and protease production was observed for 12 hours in liquid medium with $1 \%$ trisodium citrate as a carbon source in a $250 \mathrm{~mL}$ Erlenmeyer flask (Fig. 1a). Bacillus sp grew very fast and the formation of protease started from $5 \mathrm{~h}$ of the growth and reached a maximum in 9 hours $(1.93 \mathrm{U} / \mathrm{mg}$ Protein) and then began to fall. This suggests that protease production was directly linked to the culture being metabolically active. Ward (24) reported that Bacillus sp usually produce more protease during the late exponential phase. The function of this enzyme is obscure, but its production is correlated with the onset of a high rate of protein turnover during sporulation in certain bacilli.

The supplementation of the culture medium with a solution of metal traces improved substantially the growth of Bacillus sp SMIA-2 and the enzyme production (Fig. 1b), thereby indicating the requirements of some metal ions for protease production by this organism. These results corroborate the earlier findings of metal ions enhancing the activity of protease (7). Ferrero et al. (5) reported the use of trisodium citrate along with $\mathrm{MgSO}_{4}, \mathrm{CaCl}_{2}, \mathrm{MnSO}_{4}$ and $\mathrm{ZnSO}_{4}$ for protease production by Bacillus licheniformis MIR 29.

Although the addition of metal traces solution to the medium improved the growth of Bacillus sp SMIA-2 and the protease activity, a rapid loss of activity of this enzyme in the 


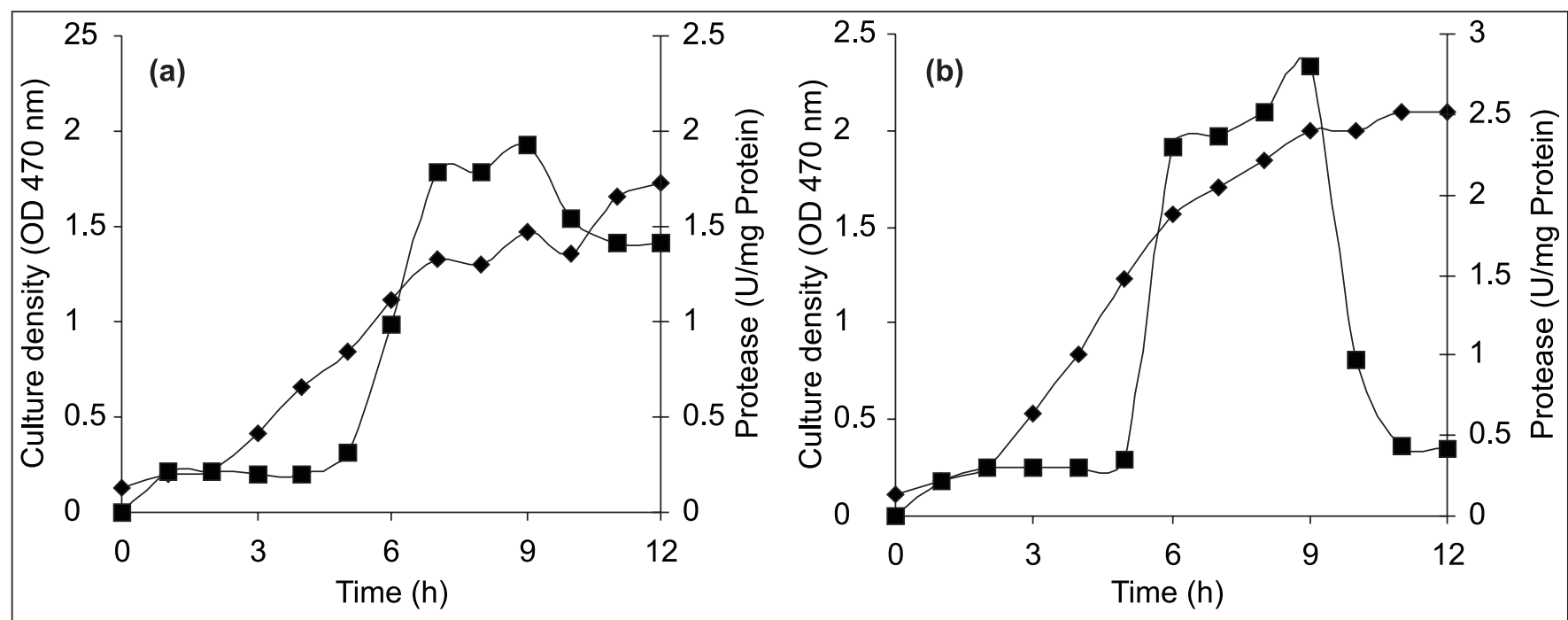

Figure 1. Growth $(\checkmark)$ and protease production $(\boldsymbol{\square})$ as a function of cultivation time by Bacillus sp SMIA-2 grown on $1.0 \%$ trisodium citrate (a) and supplemented with metal traces (b) in shake flasks at initial pH 7.0 and at $50^{\circ} \mathrm{C}$.

stationary phase culture was observed. These results are similar to the findings of Jansen et al. (7), who observed a marked decreased of proteinase activity in cultures of Thermus sp. Since $\mathrm{Ca}^{2+}$ has a significant stabilizing effect on protease, these authors suspected that chelators and phosphate were lowering the available $\mathrm{Ca}^{2+}$ in the culture. Thus, they modified the medium to remove chelators, lower the inorganic phosphate concentration and boost the $\mathrm{Ca}^{2+}$ concentration without incurring a reduction in the growth rate. These changes resulted in an improvement in the proteinase activity half-life from $5.9 \mathrm{~h}$ to $11.7 \mathrm{~h}$.

Bacillus sp SMIA-2 was capable of utilizing a wide range of carbon sources. However, the best carbon sources in the present study, for protease secretion were starch and trisodium citrate (Table 1). In a similar study Johnvesly and Nailk (8) showed that citric acid, soluble starch and trisodium citrate were the best carbon sources for protease production by Bacillus sp JB-99. According to these authors, culturing this organism in $1 \%$ glucose (w/v) repressed completely the synthesis of alkaline protease. However, in the present study glucose was found to be a relatively good carbon source for enzyme production since moderate amount of protease activity was detected.

The type of nitrogen sources also affected enzyme production. Among the various organic and inorganic nitrogen sources, the maximum enzyme activity (1.1U/mgProtein) was obtained when ammonium nitrate was used in the medium (Table 2). Moderate to good levels of enzyme activities were obtained when ammonium chloride, ammonium citrate and potassium nitrate were used as nitrogen sources. When various organic nitrogen sources were tested for protease production, it was found that protease formation by Bacillus sp SMIA-2 was repressed, although growth in some cases was stimulated. Similar results were obtained by Ponsare et al. (16) to Aeromonas hydrophila and by Banerjee et al. (3) to Bacillus brevis. On the other hand, Phadatare et al. (15) reported the enhancement of protease production in Conidiobolus coronatus by organic

Table 1. Growth and protease activity by Bacillus sp SMIA-2 using different carbon sources. The culture density and extracellular protease activity were determined after $9 \mathrm{~h}$ incubation at $50^{\circ} \mathrm{C}$ and a initial $\mathrm{pH} 7.0$.

\begin{tabular}{ccc}
\hline Carbon source & $\begin{array}{c}\text { Culture density } \\
\left(\mathrm{OD}_{470 \mathrm{~mm}}\right)\end{array}$ & $\begin{array}{c}\text { Protease activity } \\
(\mathrm{U} / \mathrm{mgProtein})\end{array}$ \\
\hline Glycerol & 0.93 & 0.36 \\
Galactose & 0.34 & 0.25 \\
Lactose & 0.39 & 0.31 \\
Sucrose & 0.67 & 0.76 \\
Maltose & 0.24 & 0.45 \\
Starch & 1.24 & 1.14 \\
Glucose & 0.50 & 0.53 \\
Manose & 0.74 & 0.74 \\
Arabinose & 0.41 & 0.15 \\
Casein & 0.41 & 0.33 \\
Xylose & 0.33 & 0.29 \\
Fructose & 0.51 & 0.22 \\
Trisodium Citrate & 0.99 & 1.11 \\
Citric acid & 0.45 & 0.79 \\
\hline
\end{tabular}


Table 2. Growth and production of protease by Bacillus sp SMIA-2 using different nitrogen sources. The culture density and extracellular protease activity were determined after $9 \mathrm{~h}$ incubation at $50^{\circ} \mathrm{C}$ and initial $\mathrm{pH}$ 7.0.

\begin{tabular}{ccc}
\hline Nitrogen source & $\begin{array}{c}\text { Culture density } \\
\left(\mathrm{OD}_{470 \mathrm{~nm}}\right)\end{array}$ & $\begin{array}{c}\text { Enzyme activity } \\
\text { (U/mgProtein) }\end{array}$ \\
\hline None & 0.25 & 0.27 \\
Peptone $(0.1 \%)$ & 0.60 & 0.28 \\
Peptone $(0.2 \%)$ & 1.10 & 0.43 \\
Peptone $(0.3 \%)$ & 1.55 & 0.29 \\
Peptone $(0.5 \%)$ & 1.49 & 0.22 \\
Peptone $(1.0 \%)$ & 1.46 & 0.05 \\
Yeast extract $(1.0 \%)$ & 1.41 & 0.13 \\
Meat extract $(1.0 \%)$ & 1.82 & $\mathrm{n} . \mathrm{d}$. \\
Casein $(1.0 \%)$ & 0.63 & 0.10 \\
Ammonium citrate $(1.0 \%)$ & 0.57 & 0.73 \\
$\mathrm{NH}_{4} \mathrm{NO}_{3}(1.0 \%)$ & 0.64 & 1.10 \\
$\left(\mathrm{NH}_{4}\right)_{2} \mathrm{HPO}_{4}(1.0 \%)$ & 0.41 & 0.18 \\
$\mathrm{NH}_{4} \mathrm{Cl}_{(1.0 \%)}$ & 1.00 & 0.76 \\
$\mathrm{KNO}_{3}(1.0 \%)$ & 0.55 & 0.59 \\
$\left(\mathrm{NH}_{4}\right)_{2} \mathrm{SO}_{4}(1.0 \%)$ & 0.24 & 0.16 \\
\hline
\end{tabular}

nitrogen sources like tryptone, peptone and yeast extract. Organic nitrogen sources have been found to be better nitrogen sources for growth and protease production in some organisms $(2,15)$ and inorganic nitrogen sources (ammonium sulphate and potassium nitrate) gave better enzyme yields in other organisms (20).

\section{Effect of $\mathrm{pH}$ on activity and stability of protease}

A pH range between 5.5 and 9.0 was used to study the effect of $\mathrm{pH}$ on protease activity (Fig. 2). Optimum $\mathrm{pH}$ was found to be 8.0 . At pH 6.5 only $29 \%$ of the maximum enzyme activity was obtained, increasing to $53 \%$ and $59 \%$ at $\mathrm{pH} 7.0$ and 7.5 , respectively. After incubation of crude enzyme solution at room temperature for $24 \mathrm{~h}$ at $\mathrm{pH}$ values of 5.5, 8.0 and 9.0, it was observed a decrease of about $51 \%, 18 \%$ and $66 \%$ of its original activity, respectively. Sookkheo et al. (22) reported to three proteases, S, $\mathrm{N}$ and B from thermophilic Bacillus stearothermophilus TLS33, optimum $\mathrm{pH}$ values of $8.5,7.5$, and 7.0 , respectively. The protease $\mathrm{S}$ was active over a very broad $\mathrm{pH}$ range, and about $60 \%$ of proteolytic activity was still detectable at $\mathrm{pH} 6$ and 10 in the presence of $5 \mathrm{mM} \mathrm{CaCl}_{2}$. In contrast, proteases $\mathrm{N}$ and B retained relatively little activity above $\mathrm{pH}$ 9.0.

\section{Effect of temperature on activity and stability of protease}

The protease activities were assayed at different temperatures ranging from $30^{\circ} \mathrm{C}-90^{\circ} \mathrm{C}$ at a constant $\mathrm{pH}$ of 7.5 (Fig. 3). Enzyme activity increased with temperature within the

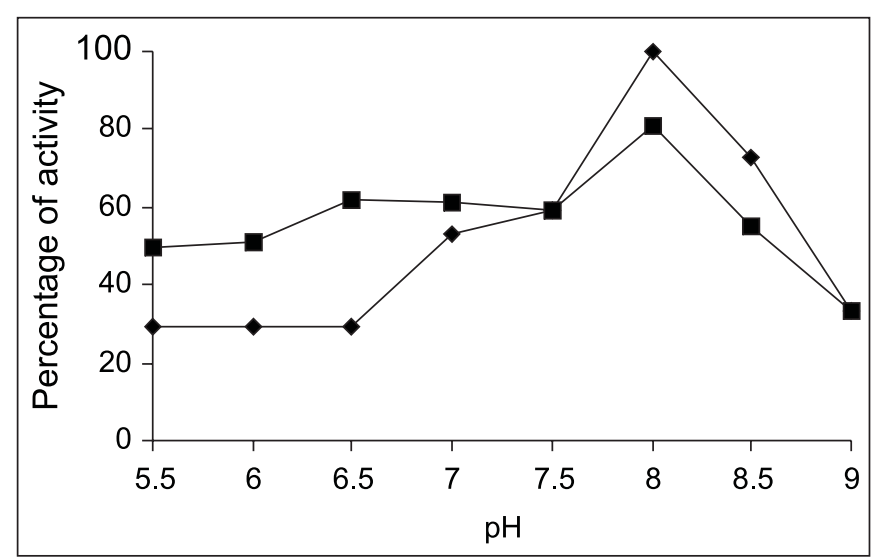

Figure 2. Optimum $\mathrm{pH}(\boldsymbol{)})$ and stability ( $\boldsymbol{\square})$ of protease produced by Bacillus sp SMIA-2 grown at $50^{\circ} \mathrm{C}$ for $9 \mathrm{~h}$. Relative activity is expressed as a percentage of the maximum (100\% of enzyme activity $=0.8 \mathrm{U} / \mathrm{mg}$ Protein).

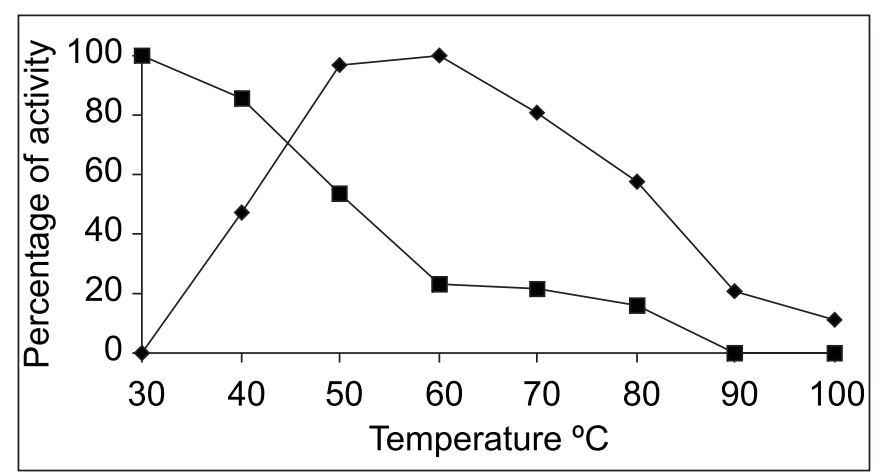

Figure 3. Optimum temperature ( $)$ and stability ( $\boldsymbol{\square}$ ) of protease produced by Bacillus sp SMIA-2 grown at $50^{\circ} \mathrm{C}$ for $9 \mathrm{~h}$. Relative activity is expressed as a percentage of the maximum (100\% of enzyme activity $=0.6 \mathrm{U} / \mathrm{mg}$ Protein).

range of $30^{\circ} \mathrm{C}$ to $60^{\circ} \mathrm{C}$. A reduction in enzyme activity was observed at values above $60^{\circ} \mathrm{C}$. The optimum temperature of this protease was $60^{\circ} \mathrm{C}$ which was similar to that described for other Bacillus proteases $(3,6)$. The thermostability of the protease was examined by measuring the remaining activities at $60^{\circ} \mathrm{C}$, after incubation of the enzyme without substrate at various temperatures between 30 and $90^{\circ} \mathrm{C}$ for $2 \mathrm{~h}$. Thermostability profile indicated that the enzyme was stable at $30^{\circ} \mathrm{C}$ for $2 \mathrm{~h}$ while at $40^{\circ} \mathrm{C}$ and $80^{\circ} \mathrm{C}, 14 \%$ and $84 \%$ of the original activities were lost, respectively. Protease from Bacillus sp. JB-99 retained 63\% and $25 \%$ original activity after $1 \mathrm{~h}$ heat treatment at 70 and $80^{\circ} \mathrm{C}$, however in the presence of $10 \mathrm{mM} \mathrm{Ca}^{2+}$, the enzyme retained $83 \%$ and $74 \%$ of the original activity, respectively (8). 


\section{Effect of metal ions on protease activity}

The effect of different metal ions on protease is shown in Table 3. A stronger inhibitory effect was observed in the presence of $\mathrm{K}^{+}, \mathrm{Cu}^{2+}$ and $\mathrm{Zn}^{2+}$. $\mathrm{Hg}^{2+}$ inhibited completely the enzyme at $1 \mathrm{mM}$ concentrations. The protease secreted by Brevibacillus (Bacillus) brevis was also inhibited by $\mathrm{Hg}^{2+}$, $\mathrm{Zn}^{2+}$ and $\mathrm{Cu}^{2+}(3)$. The inhibitory effect of heavy metal ions is well documented in the literature. It is known that the ions mercury, cadmium and lead react with the protein thiol groups (converting them to mercaptides), as well as with histidine and tryptophan residues. Moreover, by action of silver and mercury, the disulphide bonds were found to be hydrolytically degraded (9).

Protease activity was stimulated by $\mathrm{Mn}^{2+}$ and $\mathrm{Ca}^{+2}$. These results suggest that these metal ions apparently protected the enzyme against thermal denaturation and played a vital role in maintaining the active conformation of the enzyme at higher temperatures (4). Similar effects of $\mathrm{Mn}^{2+}$ on the activity of proteases were also observed by Rahman et al. (18), and by Manachini et al. (10).

Table 3. Effect of various metal ions on protease activity

\begin{tabular}{cc}
\hline Metal ions & Residual protease activity $(\%)$ \\
\hline $\mathrm{Control}_{\mathrm{CaCl}}$ & 100 \\
$\mathrm{KCl}$ & 131 \\
$\mathrm{FeSO}_{4}$ & 5 \\
$\mathrm{ZnCl}_{2}$ & 54 \\
$\mathrm{HgCl}_{2}$ & 18 \\
$\mathrm{MgSO}_{4}$ & 0 \\
$\mathrm{MnSO}_{4}$ & 61 \\
$\mathrm{CuSO}_{4}$ & 127 \\
$\mathrm{CoCl}_{2}$ & 12 \\
$\mathrm{NaCl}$ & 88 \\
\hline
\end{tabular}

The activity is expressed as a percentage of the activity level in the absence of metal ion. The enzyme was preincubated with metal ion $\left(60^{\circ} \mathrm{C}, 5 \mathrm{~min}\right.$.) Separate blanks with individual metal ions were prepared.

\section{ACKNOWLEDGMENTS}

The authors thank the FAPERJ (Fundação Carlos Chagas Filho de Amparo à Pesquisa do Estado do Rio de Janeiro) for financial support and the CNPq (Conselho Nacional de Desenvolvimento Científico e Tecnológico) for providing a scholarship to posgraduate student W.C.A.Nascimento.

\section{RESUMO}

\section{Produção e propriedades de uma protease extracelular de um Bacillus sp termofílico}

A produção de protease pelo termofílico Bacillus sp cepa SMIA-2 cultivado em culturas líquidas contendo citrato trissódico alcançou o máximo em 9h, com níveis de 1,93U/mg de proteína. O microrganismo utilizou várias fontes de carbono para a produção da protease, sendo que o amido foi o melhor substrato seguido por citrato trissódico, ácido cítrico e sacarose. Entre as várias fontes de nitrogênio orgânico e inorgânico, o nitrato de amônio foi a melhor. Estudos sobre a caracterização da protease revelaram que a temperatura ótima desta enzima foi $60^{\circ} \mathrm{C}$. A enzima foi estável por $2 \mathrm{~h}$ a $30^{\circ} \mathrm{C}$, enquanto a $40^{\circ} \mathrm{C}$ and $80^{\circ} \mathrm{C}, 14 \%$ e $84 \%$ da atividade original foram perdidas, respectivamente. $\mathrm{O}$ valor ótimo de $\mathrm{pH}$ encontrado para a enzima foi 8,0. Após a incubação da solução enzimática bruta por $24 \mathrm{~h}$ a $\mathrm{pH} 5,5,8,0$, e 9,0 foi observado um decréscimo de em torno de $51 \%, 18 \%$ e $66 \%$ da sua atividade original, respectivamente. Um forte efeito inibitório foi observado na presença de $\mathrm{K}^{+}, \mathrm{Hg}^{2+}$, $\mathrm{Cu}^{2+}$. A presença de $\mathrm{Hg}^{+}$resultou na perda completa da atividade da enzima na concentração de $1 \mathrm{mM}$. A atividade foi estimulada pela presença do $\mathrm{Mn}^{2+}$ e $\mathrm{Ca}^{+2}$, indicando que estes íons tiveram um papel funcional na estrutura molecular da enzima.

\section{Palavras-chave: protease, bactéria termofílica, Bacillus sp}

\section{REFERENCES}

1. Adams, M.W.W.; Kelly, R.M. Finding and using thermophilic enzymes. Trends Biotechnol., 16: 329-332, 1998

2. Aleksieva, P.; Djerova, A.; Tchorbanov, B.; Girarov, J. Submerged cultivation of a strain of Humicola lutea 72 producing acid protease. Eur. J. App. Microbiol. Biotech., 13: 165-169, 1981.

3. Banerjee, U.C.; Sani, R.K.; Azmi, W.; Soni, R. Thermostable alkaline protease from Bacillus brevis and its characterization as a laundry detergent additive. Proc. Biochem., 35: 213-219, 1999

4. Beg, Q.K.; Gupta, R. Purification and characterization of an oxidationstable, thiol-dependent serine alkaline protease from Bacillus mojavensis. Enz. and Microbial Techn., 32: 294-304, 2003.

5. Ferrero, M.A.; Castro, G.R.; Abate, C.M.; Baigori, M.D.; Singeriz, F. Thermostable alkaline proteases of Bacillus licheniformis MIR 29: isolation, production and characterization. Appl. Microbiol. Biotechnol., 45: 327-332, 1996.

6. Horikoshi, K. Enzymes of alkalophilies. In: Microbial Enzyme and Biotechnology, 2 ${ }^{\text {nd }}, 275-94,1990$.

7. Janssen, P.H.; Peek, K.; Morgan, H.W. Effect of culture conditions on the production of a extracellular proteinase by Thermus sp. Rt41A Appl. Microbiol. Biotechnol., 41: 400-406, 1994.

8. Johnvesly, B.; Naik, G.R. Studies on production of thermostable alkaline protease from thermophilic and alkaliphilic Bacillus sp. JB99 in a chemically defined medium. Proc. Biochem., 37: 139-144, 2001.

9. Kumar, C.G.; Tiwari, M.P.; Jany, K.D. Novel alkaline serine proteases from alkalophilic Bacillus spp.: Purification and some properties. Proc. Biochem., 34: 441-449, 1999. 
10. Manachini, P.L.; Fortina, M.G.; Parini, C. Thermostable alkaline protease produced by Bacillus thermoruber a new species of Bacillus. Appl. Microbiol., 28: 409-413, 1988.

11. Nunes, A.S. Influência da temperatura sobre os requerimentos nutricionais de um Bacillus sp. termofílico. Tese (Mestrado em Produção Vegetal) - Campos dos Goytacazes - RJ, Universidade Estadual do Norte Fluminense - UENF, 63p. 2000.

12. Nunes, A.S.; Martins, M.L.L. Isolation, properties and kinetics of growth of a thermophilic Bacillus. Braz. J. Microbiol., 32: 271-275, 2001.

13. Pastor, M.D.; Lorda, G.S.; Balatti, A. Protease obtention using Bacillus subtilis 3411 and amaranth seed meal medium at different aeration rates. Braz. J. Microbiol., 32: 1-8, 2001.

14. Peterson, G.L. A simplification of the protein assay method of Lowry et al. which is more generally applicable. Analytical Biochem., 83: 346-356, 1977.

15. Phadatare, S.U.; Deshpande, V.V.; Srinivasan, M.C. High activity alkaline protease from Conidiobolus coronatus (NCL 86.8.20): Enzyme production and compatability with commercial detergents. Enz. Microbiol. Technol., 15: 72-76, 1993.

16. Ponsare, A.C.; Venugopal, V.; Lewis, N.F. A note on nutritional influence on extracellular protease synthesis in Aeromonas hydrophila. J. Appl. Bacteriol., 58: 101-104.
17. Priest, F.G. Extracellular enzyme synthesis in the genus Bacillus. Bacteriol. Rev., 41: 711-753, 1977.

18. Rahman, R.N.Z.A.; Razak, C.N.; Ampom, K.; Basri, M.; Yunus, W.M.Z.W.; Salleh, A.B. Purification and characterization of a heatstable alkaline protease from Bacillus stearothermophilus F1. Appl. Microbiol. Biotechnol., 40: 822-827, 1994.

19. Singh, J.; Batra, N.; Sobti, C.R. Serine alkaline protease from a newly isolated Bacillus sp. SSR1. Proc. Biochem., 36: 781-785, 2001.

20. Sinha, N.; Satyanarayana, T. Alkaline protease by thermophilic Bacillus licheniformis. Indian J. Microbiol., 31: 425-430, 1991.

21. Sonnleitner, B.; Fiechter, A. Advantages of using thermophiles in biotechnological processes: expectations and reality. Trends Biotechnol., 1: 74-80, 1983 .

22. Sookkheo, B.; Sinchaikul, S.; Phutrakul, S.; Chen, S.T. Purification and characterization of the highly thermostable proteases from Bacillus stearothermophilus TLS33. Prot. Exp. Pur., 20: 142-151, 2000.

23. Zeikus, J.G.; Vieille, C.; Savchenko, A. Thermozymes: Biotechnology and structure-function relationship. Extremophiles, 1: 2-13, 1998.

24. Ward, O.P. Proteolytic enzymes. In: M. Moo-Young Editor, Comprehensive Biotechnol., 3: 789-818, 1985. 